\title{
SISTEM PAKAR DIAGNOSA PENYAKIT PARU-PARU MENGGUNAKAN METODE NAIVE BAYES CLASSIFIER BERBASIS JAVA
}

\author{
Ahmad Buchori' ${ }^{1}$, Siti Khotijah², Ade Syahrul Ramdan \\ ${ }^{1,2,3}$ Teknik Informatika, Fakultas Teknik dan Ilmu Komputer, Universitas Indraprasta PGRI \\ Jalan Raya Tengah No 80, Kelurahan Gedong, Pasar Rebo, Jakarta Timur \\ ${ }^{1}$ ahmadbuchori41@gmail.com, ${ }^{2}$ sitik2805@gmail.com, ${ }^{3}$ as.ramdan13@gmail.com
}

\begin{abstract}
ABSTRAK
Sejalan dengan penerapan ilmu komputer yang semakin meluas serta pesatnya perkembangan teknologi informasi, memberikan dampak positif pada bidang kesehatan saat ini. Dengan adanya perkembangan teknologi informasi pada bidang kesehatan, dapat meningkatkan pelayanan kesehatan menjadi lebih baik. Salah satu implementasinya adalah untuk melakukan diagnosa penyakit paru-paru. Penyakit paru-paru menjadi hal yang penting untuk diperhatikan mengingat paru-paru merupakan salah satu organ vital manusia yang menjadi penyebab kematian terbesar di dunia. Selain dari itu, keterbatasan informasi serta mahalnya biaya pengobatan merupakan salah satu penyebab munculnya permasalahan yang lebih luas pada penanganan penyakit paruparu. Pada penelitian ini dibangun suatu aplikasi sistem pakar berbasis java guna membantu konsultasi bagi pasien penderita penyakit paru-paru. Metode yang diterapkan adalah Naive Bayes Classifier. Pada penelitian ini telah dihasilkan sebuah aplikasi yang bertujuan untuk mendiagnosa penyakit paru-paru secara offline, pasien cukup mendaftar pada petugas klinik (bagian administrasi) serta menyebutkan gejala-gejala yang dialaminya tanpa perlu berkonsultasi secara langsung dengan dokter spesialis paru-paru sehingga proses pelayanan menjadi lebih efektif dan efisien. Berdasarkan hasil percobaan kepada 12 orang pasien penyakit paru-paru menggunakan sistem, prosentase kesesuaian diagnosa penyakit paru-paru jika dibandingkan dengan hasil diagnosa dari pakar sebenarnya sebesar $83 \%$.
\end{abstract}

Kata Kunci: Sistem Pakar, Penyakit Paru-paru, Naive Bayes Classifier, Java

\begin{abstract}
In line with the increasingly widespread application of computer science and the rapid development of information technology, it has a positive impact on the health sector today. With the development of information technology in the health sector, it can improve health services for the better. One of the implementations is to diagnose lung disease. Lung disease is an important thing to pay attention to considering that the lungs are one of the vital human organs that are the biggest cause of death in the world. In addition, limited information and the high cost of treatment are one of the causes of the emergence of wider problems in the treatment of lung disease. In this study, a java-based expert system application was built to assist consultation for lung disease patients. The method applied is Naive Bayes Classifier. In this study an application was produced that aims to diagnose lung disease offline, patients simply register with the clinic officer (administrative section) and mention the symptoms they are experiencing without the need to go directly to a lung specialist so that the service becomes more effective and efficient. efficient. Based on the results of experiments on 12 patients with lung disease using the system, the percentage according to the diagnosis of lung disease when compared with the results of the diagnosis from the real expert was $83 \%$.
\end{abstract}

Key Word: Expert System, Lung Disease, Naive Bayes Classifier, Java

\section{PENDAHULUAN}

Paru-paru merupakan salah satu organ vital manusia yang fungsinya sebagai alat pernafasan yang apabila tidak berfungsi dengan baik maka akan menyebabkan kematian (Amalia et al., 2017). Berdasarkan data dari Global Cancer Statistics (Globocan) 2020, jumlah kasus kanker paru-paru di Indonesia meningkat sebanyak 34.783 kasus dengan angka kematian sebanyak 30.843 orang (Putri, 2021). Berdasarkan data dari TB
Indonesia tahun 2020, angka kematian akibat TBC di Indonesia meningkat menjadi 98.000 orang dengan kasus baru mencapai 845.000 kasus (Pusat Layanan Kesehatan, 2021). Berdasarkan data-data tersebut, penyakit paru-paru di Indonesia menjadi masalah yang serius sehingga mengharuskan adanya penanganan dan pengobatan yang tepat serta cepat guna mengatasi permasalahan tersebut. 
Banyaknya jenis penyakit paru-paru dan memiliki gejala yang hampir mirip terkadang membuat masyarakat tidak mengetahui dengan jelas penyakit paru-paru apa yang sedang mereka derita. Oleh karena itu, konsultasi antara pasien dengan dokter spesialis sangat penting guna mengetahui dan mengatasi penyakit pasien berdasarkan gejala-gejala yang dialami pasien. Konsultasi dilakukan dengan langsung bertatap muka pada dokter spesialis dimana biasanya pasien harus mendaftar dan mengantre terlebih dahulu.

Sistem pakar merupakan suatu aplikasi komputer yang dapat membantu pengambilan keputusan atau pemecahan persoalan dalam bidang yang spesifik dengan menggunakan pengetahuan dan metode analisis yang telah didefinisikan terlebih dahulu oleh pakar yang sesuai dengan bidang keahliannya. Sistem pakar dapat meningkatkan produktivitas karena dapat bekerja lebih cepat daripada manusia serta membuat orang awam bekerja seperti layaknya seorang pakar (Hayadi, 2018).

Penelitian pertama yang menjadi sumber rujukan yaitu penelitian oleh Dhevi Dadi Kusumaningtyas, Muhammad Hasbi, dan Hendro Wijayanto dengan judul Sistem Pakar Diagnosa Penyakit Saluran Pernafasan dengan Metode Fuzzy Tsukamoto. Penelitian ini menghasilkan sebagian data-data gejala dan penyakit paru-paru, sebagai acuan untuk membuat aplikasi yang baik dan benar sesuai dengan yang diharapkan. Hasil menunjukkan prosentase kesesuaian diagnosis adalah $80 \%$. (Kusumaningtyas et al., 2019)

Penelitian lainnya oleh Yusuf Ramadhan Nasution dan Khairuna dengan judul Sistem Pakar Deteksi Awal Penyakit Tuberkulosis dengan Metode Bayes. Sistem yang dihasilkan berupa penggunaan metode inferensi Bayes. (Nasution \& Khairuna, 2017)

Selain itu, penelitian oleh Firmansyah Putra dengan judul Perancangan Sistem Pakar Identifikasi Penyakit Paru-paru Menggunakan Metode Forward Chaining. Sistem yang dihasilkan berupa pengunaan pemodelan Flowchart. (Putra, 2011)
Penelitian ini bertujuan untuk membuat sistem pakar diagnosa penyakit paru-paru yang dapat dioperasikan secara offline oleh petugas klinik sehingga dapat mempercepat proses pendiagnosaan penyakit pasien serta mempermudah dalam pembuatan laporan dan perhitungan statistik penderita penyakit berdasarkan periode waktu tertentu.

Manfaat yang didapat dari penelitian ini yaitu pasien tidak perlu menunggu lama untuk berkonsultasi dengan dokter, melainkan cukup mendaftarkan diri pada bagian administrasi kemudian menyebutkan gejalagejala yang dialaminya dan langsung mengetahui hasil diagnosa penyakit yang dideritanya sehingga proses pelayanan dapat lebih efektif dan efisien. Berbeda dengan pelayanan sebelum dibuatnya sistem yang mengharuskan pasien untuk mendaftar terlebih dahulu pada bagian administrasi kemudian menunggu lama dalam antrean untuk berkonsultasi dengan dokter.

Keterbaharuan penelitian ini dibandingkan dengan penelitian-penelitian terdahulu yaitu hanya memerlukan jumlah data pelatihan (training data) yang kecil untuk menentukan estimasi parameter yang diperlukan dalam proses pengklasifikasian serta memiliki tingkat akurasi yang sangat baik dengan prosentase sebesar $83 \%$.

\section{METODE PENELITIAN}

Peneliti menggunakan metode Grounded Research dalam penyelesaian penelitian ini. Grounded Research merupakan penelitian berdasarkan data dan fakta untuk menghasilkan atau mengembangkan teori, bukan untuk membuktikan teori (Rahardjo, 2011).

Penelitian dilaksanakan di Klinik Aras, jalan Srengseng Sawah RT.01 RW.09, Kelurahan Srengseng Sawah, Kecamatan Jagakarsa, Kota Jakarta Selatan. Desain penelitian yaitu tahapan yang akan dilakukan peneliti untuk merencanakan dan melaksanakan suatu penelitian (Nazir, 2014).

Berikut tahapan penelitian yang dilakukan:

1. Menentukan kebutuhan data yang digunakan.

2. Wawancara dilakukan kepada narasumber yang merupakan ahli atau pakar dalam hal 
ini dokter paru-paru untuk mendapatkan informasi yang dibutuhkan mengenai permasalahan dan hal-hal yang dibutuhkan selama proses pembuatan dan pengembangan aplikasi yaitu data gejalagejala dan penyakit paru-paru. Penulis melakukan wawancara kepada dr. Seri Anni Nasution selaku dokter yang bekerja pada Klinik Aras.

3. Studi pustaka dilakukan dengan cara membaca dan mempelajari data dan informasi dari buku-buku, artikel-artikel, jurnal-jurnal, dan lain-lain yang terkait serta relevan dengan objek yang akan diteliti.

Analisa sistem berisi langkah kerja menyeluruh dari sistem pakar yang akan dibangun guna mempermudah implementasi dan pengujian sistem pakar diagnosa penyakit paru-paru menggunakan metode Naive Bayes Classifier. Algoritma Naive Bayes Classifier merupakan salah satu metode pengklasifikasian yang memprediksi menggunakan probabilitas dan statistik berdasarkan pengalaman di masa sebelumnya serta memiliki asumsi yang kuat dan tingkat akurasi yang tinggi dibandingkan dengan metode pengklasifikasian lainnya (Sanubari et al., 2020).

Langkah kerja dalam sistem pakar disesuaikan dengan arsitekur sistem pakar sebagai berikut:

1. Petugas Klinik (bagian administrasi) menginput data pasien yang akan didiagnosa.

2. Kemudian bagian administrasi menanyakan gejala-gejala apa saja yang dialami pasien.

3. Setelah pasien menyebutkan semua gejalagejala yang dialaminya, bagian administrasi menekan tombol "Mulai Diagnosa" untuk menampilkan hasil diagnosa penyakit paru-paru pasien.

4. Bagian administrasi menekan tombol simpan untuk menyimpan data serta mencetak lembar hasil diagnosa penyakit pasien yang berisi kode diagnosa, tanggal diagnosa, nama pasien, nama penyakit, dan cara penanganan penyakit.

Untuk proses pengklasifikasian penyakit paru-paru menggunakan Algoritma Naive Bayes Classifier adalah sebagai berikut:
1. Menentukan nilai $\mathrm{n}_{\mathrm{c}}$ untuk setiap gejala yang dialami pasien per penyakit

2. Mengitung nilai $\mathrm{P}\left(\mathrm{g}_{\mathrm{i}} \mid \mathrm{p}_{\mathrm{j}}\right)$ dan $\mathrm{P}\left(\mathrm{p}_{\mathrm{j}}\right)$ dimana: $\boldsymbol{P}\left(\boldsymbol{g}_{\boldsymbol{i}} \mid \boldsymbol{p}_{\boldsymbol{j}}\right)=\frac{\boldsymbol{n}_{\boldsymbol{c}}+\boldsymbol{g} \cdot \boldsymbol{p}}{\boldsymbol{n}+\boldsymbol{g}}$

Keterangan:

$\mathrm{P}\left(\mathrm{g}_{\mathrm{i}} \mid \mathrm{p}_{\mathrm{j}}\right)=$ Peluang gejala ke-i jika diketahui keadaan jenis penyakit paru-paru ke-j.

$\mathrm{n}_{\mathrm{c}}=$ jumlah record pada data learning yang gejalanya $=g_{i}$ dan penyakitnya

$$
=\mathrm{p}_{\mathrm{j}}
$$

$\mathrm{p}=1 /$ banyaknya penyakit pada database

$\mathrm{g}=$ banyaknya gejala pada database

$\mathrm{n}=$ jumlah record pada data learning yang gejalanya $=\mathrm{g}_{\mathrm{j}}$ tiap class

3. Mengitung $P\left(g_{i} \mid p_{j}\right) \times P\left(p_{j}\right)$ untuk tiap penyakit

4. Menentukan hasil klasifikasi yaitu penyakit yang memiliki hasil perkalian terbesar

\section{HASIL DAN PEMBAHASAN}

Berdasarkan akuisisi pengetahuan yang didapat dari ahli atau pakar. Maka didapat 12 penyakit dengan 37 gejala. Daftar penyakit dan gejala dapat dilihat pada Tabel 1 dan Tabel 2. Dari penyakit dan gejala tersebut di hasilkan relasi antar penyakit dan gejala yang dapat dilihat pada Tabel 3. Perancangan aplikasi diagnosa penyakit pada paru-paru ini menggunakan perancangan Flowchart dan Pseudocode.

Tabel 1. Daftar Penyakit Paru-paru

\begin{tabular}{|c|c|l|}
\hline No & $\begin{array}{c}\text { Kode } \\
\text { Penyakit }\end{array}$ & \multicolumn{1}{|c|}{ Nama Penyakit } \\
\hline 1. & P01 & Pneumonia \\
\hline 2. & P02 & Tuberkulosis (TBC) \\
\hline 3. & P03 & Bronkitis \\
\hline 4. & P04 & Asma \\
\hline 5. & P05 & Emfisema \\
\hline 6. & P06 & Efusi Pleura \\
\hline 7. & P07 & Pneumotoraks \\
\hline 8. & P08 & Silikosis \\
\hline 9. & P09 & Asbestosis \\
\hline 10. & P10 & Obstruktif Kronis (PPOK) \\
\hline 11. & P11 & Influenza \\
\hline 12. & P12 & Covid-19 \\
\hline
\end{tabular}

Tabel 2. Daftar Gejala Penyakit Paru-paru

\begin{tabular}{|c|c|l|}
\hline No & $\begin{array}{c}\text { Kode } \\
\text { Gejala }\end{array}$ & \multicolumn{1}{|c|}{ Nama Gejala } \\
\hline 1. & G01 & $\begin{array}{l}\text { Memiliki riwayat tekanan } \\
\text { darah tinggi (hipertensi) }\end{array}$ \\
\hline 2. & G02 & Penderita penyakit jantung \\
\hline 3. & G03 & Pengidap diabetes \\
\hline 4. & G04 & $\begin{array}{l}\text { Pengidap penyakit refluks } \\
\text { asam lambung (GERD) }\end{array}$ \\
\hline
\end{tabular}




\begin{tabular}{|c|c|c|}
\hline 5. & G05 & $\begin{array}{l}\text { Orang tua memiliki riwayat } \\
\text { penyakit asma }\end{array}$ \\
\hline 6. & G06 & $\begin{array}{l}\text { Sering berhubungan dengan } \\
\text { pasien penderita TBC }\end{array}$ \\
\hline 7. & G07 & $\begin{array}{l}\text { Sering terkena paparan debu } \\
\text { asbes atau silika }\end{array}$ \\
\hline 8. & G08 & $\begin{array}{l}\text { Sering terpapar perubahan } \\
\text { tekanan atmosfer dan cuaca } \\
\text { yang ekstrem }\end{array}$ \\
\hline 9. & G09 & $\begin{array}{l}\text { Pernah mengalami cedera } \\
\text { atau benturan yang keras di } \\
\text { dada }\end{array}$ \\
\hline 10. & G10 & $\begin{array}{l}\text { Kebiasaan merokok atau } \\
\text { menghirup asap rokok }\end{array}$ \\
\hline 11. & G11 & Batuk berdahak \\
\hline 12. & G12 & Batuk tidak berdahak \\
\hline 13. & G13 & $\begin{array}{l}\text { Batuk disertai lendir } \\
\text { berwarna kuning keabu- } \\
\text { abuan atau hijau }\end{array}$ \\
\hline 14. & G14 & Batuk berdahak > 3 minggu \\
\hline 15. & G15 & Batuk darah \\
\hline 16. & G16 & $\begin{array}{l}\text { Pilek (hidung beringus atau } \\
\text { tersumbat) }\end{array}$ \\
\hline 17. & G17 & Sakit tenggorokan \\
\hline 18. & G18 & Diare \\
\hline 19. & G19 & Nyeri otot \\
\hline 20. & $\mathrm{G} 20$ & Pusing / sakit kepala \\
\hline 21. & $\mathrm{G} 21$ & Nafsu makan berkurang \\
\hline 22. & $\mathrm{G} 22$ & $\begin{array}{l}\text { Mengalami penurunan berat } \\
\text { badan }\end{array}$ \\
\hline 23. & G23 & Mual dan muntah \\
\hline 24. & $\mathrm{G} 24$ & Mudah lelah \\
\hline 25. & $\mathrm{G} 25$ & Demam dan menggigil \\
\hline 26. & G26 & $\begin{array}{l}\text { Demam dan berkeringat } \\
\text { pada malam hari }\end{array}$ \\
\hline 27. & G27 & Keluar keringat dingin \\
\hline 28. & G28 & Gangguan pada kesadaran \\
\hline 29. & G29 & Sesak nafas \\
\hline 30. & G30 & $\begin{array}{l}\text { Nyeri dada pada saat } \\
\text { bernafas dan batuk }\end{array}$ \\
\hline 31. & G31 & $\begin{array}{l}\text { Kesulitan bernafas terutama } \\
\text { saat berbaring }\end{array}$ \\
\hline 32. & G32 & $\begin{array}{l}\text { Mengi (suara bernada tinggi } \\
\text { saat bernafas) }\end{array}$ \\
\hline 33. & G33 & $\begin{array}{l}\text { Nafas terasa sesak dan berat } \\
\text { setelah terkena debu }\end{array}$ \\
\hline 34. & G34 & Sensasi tertarik di dada \\
\hline 35. & G35 & $\begin{array}{l}\text { Bengkak pada kaki, } \\
\text { pergelangan kaki, atau betis }\end{array}$ \\
\hline 36. & G36 & $\begin{array}{l}\text { Kuku jari tangan menjadi } \\
\text { bulat, melebar, atau } \\
\text { membesar (jari tabuh) }\end{array}$ \\
\hline 37. & G37 & $\begin{array}{l}\text { Bibir dan kuku membiru } \\
\text { (Sianosis) }\end{array}$ \\
\hline
\end{tabular}

\begin{tabular}{|c|l|l|}
\hline 6. & P06 & $01,07,10,12,25,29,30,31$ \\
\hline 7. & P07 & $07,08,09,10,27,29,30,34,37$ \\
\hline 8. & P08 & $07,12,21,22,24,25,26,30$ \\
\hline 9. & P09 & $07,12,21,22,24,29,30,32,36$ \\
\hline 10. & P10 & $10,14,21,22,29,32,35,37$ \\
\hline 11. & P11 & $11,12,16,17,19,20,25$ \\
\hline 12. & P12 & $11,16,17,18,19,20,23,25,30$ \\
\hline
\end{tabular}

Contoh perhitungan dengan menggunakan klasifikasi Naive Bayes Classifier dapat diterapkan pada pasien yang mengalami gejala nomor 28, 29, dan 37 .

Keterangan gejala :

28. Gangguan pada kesadaran

29. Sesak nafas

37. Bibir dan kuku membiru (Sianosis)

Langkah-langkah perhitungan Naive Bayes Classifier sebagai berikut:

1. Menentukan nilai $\mathrm{n}_{\mathrm{c}}$ untuk setiap gejala yang dialami pasien per penyakit

a. Penyakit paru-paru ke-1 : Pneumonia

$\mathrm{n}=1$

$\mathrm{p}=1 / 12=0.083$

$\mathrm{g}=37$

28. $\mathrm{n}_{\mathrm{c}}=1$

29. $\mathrm{n}_{\mathrm{c}}=1$

37. $n_{c}=0$

b. Penyakit paru-paru ke-2 : Tuberkulosis (TBC)

$\mathrm{n}=1$

$\mathrm{p}=1 / 12=0.083$

$\mathrm{g}=37$

28. $\mathrm{n}_{\mathrm{c}}=0$

29. $\mathrm{n}_{\mathrm{c}}=1$

37. $\mathrm{n}_{\mathrm{c}}=0$

dan seterusnya hingga penyakit paru-paru ke-12.

2. Mengitung nilai $P\left(g_{i} \mid p_{j}\right)$ dan $P\left(p_{j}\right)$

a. Penyakit paru-paru ke-1 : Pneumonia

$$
\begin{aligned}
& \mathrm{P}(28 \mid \mathrm{A})=(1+37 \times 0.083) /(1+37) \\
&=0.107 \\
& \mathrm{P}(29 \mid \mathrm{A})=(1+37 \times 0.083) /(1+37) \\
&=0.107 \\
& \mathrm{P}(37 \mid \mathrm{A})=(0+37 \times 0.083) /(1+37) \\
&=0.081 \\
& \mathrm{P}(\mathrm{A})=1 / 12=0.083
\end{aligned}
$$

Tabel 3. Daftar Relasi Antar Penyakit dan Gejala

\begin{tabular}{|c|c|l|}
\hline No & $\begin{array}{c}\text { Kode } \\
\text { Penyakit }\end{array}$ & \multicolumn{1}{|c|}{ Kode Gejala No. } \\
\hline 1. & P01 & $\begin{array}{l}02,10,11,18,21,23,24,25, \\
28,29,30\end{array}$ \\
\hline 2. & P02 & $\begin{array}{l}03,06,10,14,15,21,22,24, \\
26,29\end{array}$ \\
\hline 3. & P03 & $04,10,13,16,17,24,25,29,30$ \\
\hline 4. & P04 & $05,24,28,29,32,33$ \\
\hline 5. & P05 & $24,28,29,37$ \\
\hline
\end{tabular}

b. Penyakit paru-paru ke-2 : Tuberkulosis

(TBC)

$$
\begin{aligned}
\mathrm{P}(28 \mid \mathrm{B}) & =(0+37 \times 0.083) /(1+37) \\
& =0.081 \\
\mathrm{P}(29 \mid \mathrm{B}) & =(1+37 \times 0.083) /(1+37) \\
& =0.107 \\
\mathrm{P}(37 \mid \mathrm{B}) & =(0+37 \times 0.083) /(1+37) \\
& =0.081 \\
\mathrm{P}(\mathrm{B}) & =1 / 12=0.083
\end{aligned}
$$


dan seterusnya hingga penyakit paru-paru ke-12.

3. Mengitung $P\left(g_{i} \mid p_{j}\right) \times P\left(p_{j}\right)$ untuk tiap penyakit

a. Penyakit paru-paru ke-1 : Pneumonia

$\mathrm{P}(\mathrm{A}) \times[\mathrm{P}(28 \mid \mathrm{A}) \times \mathrm{P}(29 \mid \mathrm{A}) \times \mathrm{P}(37 \mid \mathrm{A})$

$=0.083 \times 0.107 \times 0.107 \times 0.081$

$=7.6971627 \mathrm{e}^{-5}$

b. Penyakit paru-paru ke-2 : Tuberkulosis (TBC)

$\mathrm{P}(\mathrm{B}) \times[\mathrm{P}(28 \mid \mathrm{B}) \times \mathrm{P}(29 \mid \mathrm{B}) \times \mathrm{P}(37 \mid \mathrm{B})$

$=0.083 \times 0.081 \times 0.107 \times 0.081$

$=5.8268241 \mathrm{e}^{-5}$

dan seterusnya hingga penyakit paru-paru ke-12.

4. Menentukan hasil klasifikasi yaitu penyakit yang memiliki hasil perkalian terbesar

Tabel 4. Hasil Perhitungan Probabilitas

\begin{tabular}{|l|l|}
\hline \multicolumn{1}{|c|}{ Nama Penyakit } & Probabilitas \\
\hline Pneumonia & $7.6971627 \mathrm{e}^{-5}$ \\
\hline Tuberkulosis (TBC) & $5.8268241 \mathrm{e}^{-5}$ \\
\hline Bronkitis & $5.8268241 \mathrm{e}^{-5}$ \\
\hline Asma & $7.6971627 \mathrm{e}^{-5}$ \\
\hline Emfisema & $1.0167856 \mathrm{e}^{-4}$ \\
\hline Efusi Pleura & $5.8268241 \mathrm{e}^{-5}$ \\
\hline Pneumotoraks & $7.6971627 \mathrm{e}^{-5}$ \\
\hline Silikosis & $4.4109603 \mathrm{e}^{-5}$ \\
\hline Asbestosis & $5.8268241 \mathrm{e}^{-5}$ \\
\hline $\begin{array}{l}\text { Obstruktif Kronis } \\
\text { (PPOK) }\end{array}$ & $7.6971627 \mathrm{e}^{-5}$ \\
\hline Influenza & $4.4109603 \mathrm{e}^{-5}$ \\
\hline Covid-19 & $4.4109603 \mathrm{e}^{-5}$ \\
\hline
\end{tabular}

Karena nilai $1.0167856 \mathrm{e}^{-4}$ paling besar, maka contoh kasus pasien diklasifikasikan sebagai penyakit Emfisema.

Berdasarkan hasil percobaan kepada 12 orang pasien penyakit paru-paru menggunakan sistem, prosentase kesesuaian diagnosa penyakit paru-paru jika dibandingkan dengan hasil diagnosa dari pakar sebenarnya sebesar 83\%. Perbandingan hasil diagnosa antara sistem pakar dengan pakar sebenarnya (human expert) dapat dilihat pada Tabel 5.

Tabel 5. Perbandingan hasil diagnosa antara sistem pakar dengan pakar sebenarnya

\begin{tabular}{|c|l|l|}
\hline $\begin{array}{c}\text { Pasien } \\
\text { ke- }\end{array}$ & $\begin{array}{c}\text { Diagnosa sistem } \\
\text { pakar }\end{array}$ & \multicolumn{1}{|c|}{ Diagnosa Pakar } \\
\hline 1 & Pneumonia & Pneumonia \\
\hline 2 & Tuberkulosis (TBC) & Tuberkulosis (TBC) \\
\hline 3 & Bronkitis & Bronkitis \\
\hline 4 & Covid-19 & Covid-19 \\
\hline
\end{tabular}

\begin{tabular}{|c|l|l|}
\hline 5 & Emfisema & Emfisema \\
\hline 6 & Efusi Pleura & Efusi Pleura \\
\hline 7 & Pneumotoraks & Pneumotoraks \\
\hline 8 & Silikosis & Asbestosis \\
\hline 9 & Asbestosis & Asbestosis \\
\hline 10 & Influenza & Covid-19 \\
\hline 11 & Asma & Asma \\
\hline 12 & $\begin{array}{l}\text { Obstruktif Kronis } \\
\text { (PPOK) }\end{array}$ & $\begin{array}{l}\text { Obstruktif Kronis } \\
\text { (PPOK) }\end{array}$ \\
\hline
\end{tabular}

Flowchart dan Pseudocode Form Login

Flowchart Form Login:

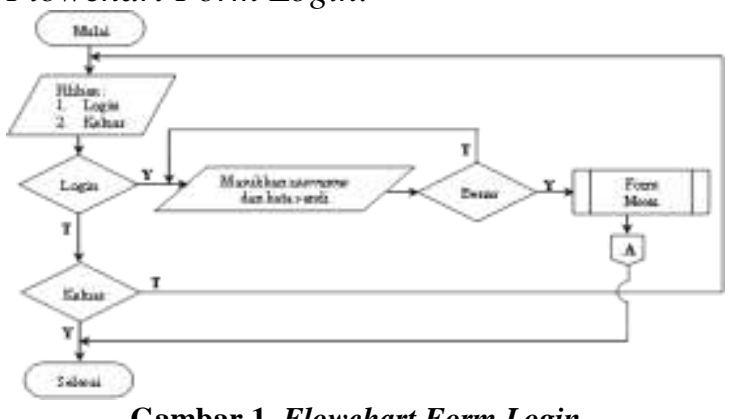

Gambar 1. Flowchart Form Login

Pseudocode Form Login:

Begin

if pilih = "Login" then Begin

Masukkan username dan kata sandi

if username and kata sandi = true then Begin

Tampilkan form Menu Utama

else

Masukkan username dan kata sandi

End if

End if

if pilih = "Keluar" then Begin

Keluar dari form Login

End if

End.

Flowchart dan Pseudocode Form Menu

Utama

Flowchart Form Menu Utama:

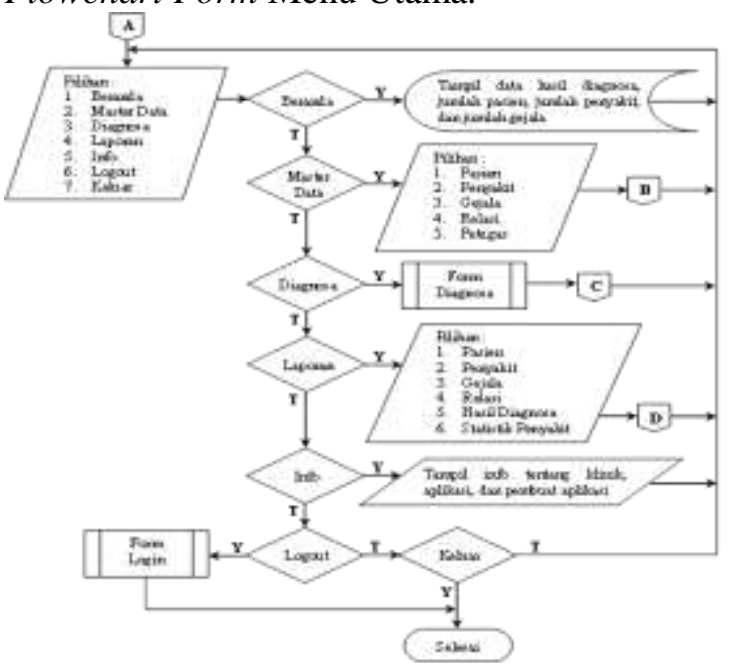

Gambar 2. Flowchart Form Menu Utama

5 | Sistem Pakar Diagnosa Penyakit Paru-paru Menggunakan Metode Naive Bayes Classifier Berbasis Java 
Pseudocode Form MenuUtama:

Begin

if pilih = "Beranda" then Begin

Menampilkan data hasil diagnosa, jumlah pasien, jumlah penyakit, dan jumlah gejala yang tersimpan pada database

End if

if pilih = "Master Data" then Begin

Menampilkan pilihan form master data

End if

if pilih = "Diagnosa" then Begin

Menampilkan form diagnosa

End if

if pilih = "Laporan" then Begin

Menampilkan pilihan form laporan

End if

if pilih = "Info" then Begin

Menampilkan info tentang klinik, aplikasi, dan pembuat aplikasi

End if

if pilih = "Logout" then Begin

Kembali ke form Login

End if

if pilih = "Keluar" then Begin

Keluar dari form Menu Utama

End if

End.

Flowchart dan Pseudocode Form Diagnosa

Flowchart Form Diagnosa:

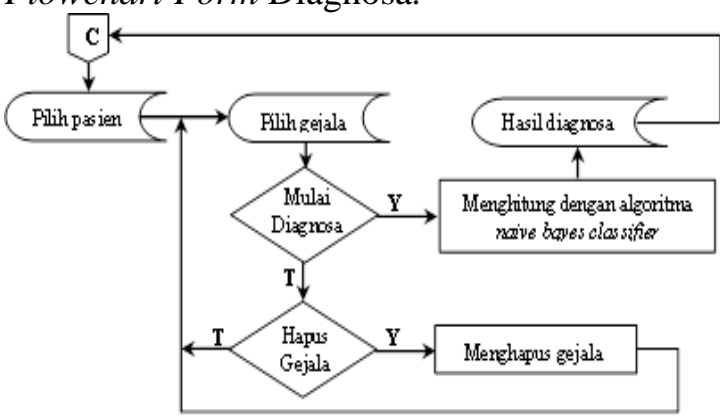

Gambar 3. Flowchart Form Diagnosa

Pseudocode Form Diagnosa:

Begin

Pilih data pasien dari database

Pilih data gejala dari database

If Mulai Diagnosa $=$ true then Begin

Hitung dengan algoritma Naive Bayes

Classifier

Simpan data hasil diagnosa pada database

End if

If Hapus Gejala = true then Begin

Hapus gejala yang dialami pasien

End if

End
Tampilan Layar

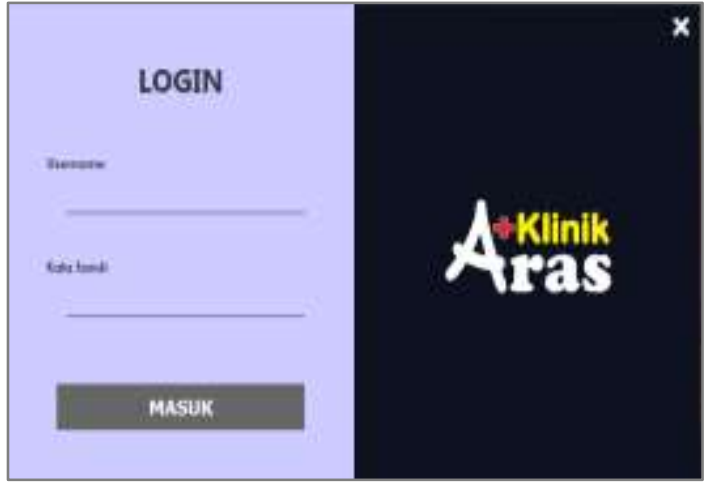

Gambar 4. Tampilan Form Login

Halaman login muncul saat pengguna membuka aplikasi, pengguna diharuskan untuk memasukkan username dan kata sandi yang benar sebelum memasuki halaman menu utama. Setelah itu, tekan tombol masuk untuk melanjutkan proses ke halaman menu utama.

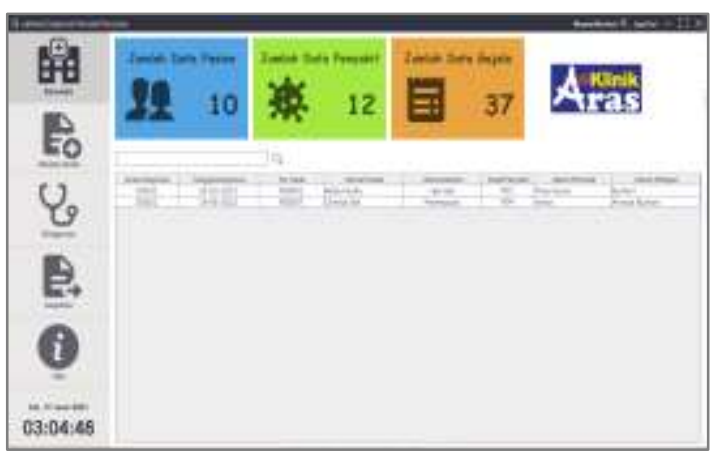

Gambar 5. Tampilan Form Menu Utama

Halaman menu utama menampilkan menu pilihan yaitu beranda, master data, diagnosa, laporan, dan info. Terdapat tombol logout untuk kembali ke halaman login.

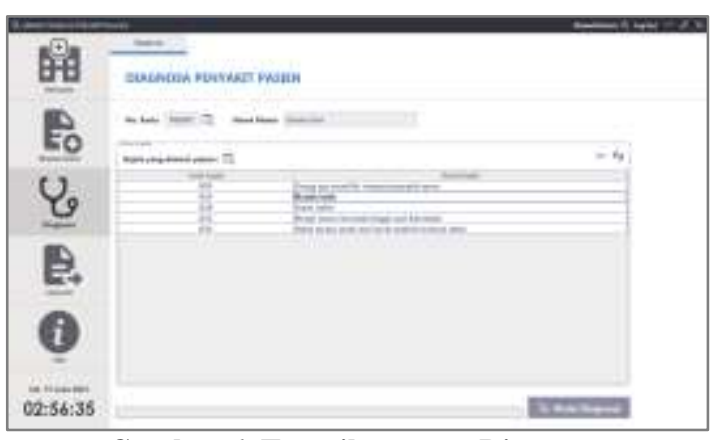

Gambar 6. Tampilan Form Diagnosa

Pada halaman diagnosa terdapat icon pilih pasien untuk memilih pasien yang akan didiagnosa, icon pilih gejala untuk memilih gejala-gejala yang dialami pasien, icon hapus gejala terpilih untuk menghapus gejala yang telah dipilih pada tabel, icon hapus semua

6 | Sistem Pakar Diagnosa Penyakit Paru-paru Menggunakan Metode Naive Bayes Classifier Berbasis Java 
gejala untuk menghapus semua gejala yang telah dimasukkan, dan tombol mulai diagnosa untuk memulai proses diagnosa penyakit paru-paru pasien berdasarkan input-an gejalagejala yang dialami pasien.

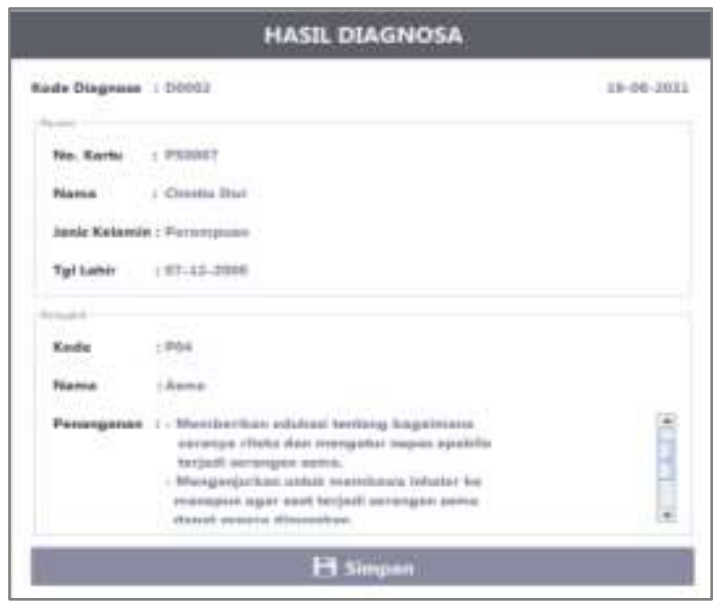

Gambar 7. Tampilan Form Hasil Diagnosa

Halaman hasil diagnosa akan tampil ketika pengguna telah mengisikan nomor kartu pasien serta semua gejala-gejala yang dialami pasien dan menekan tombol mulai diagnosa. Terdapat tombol simpan untuk menyimpan data hasil diagnosa dan kembali ke menu utama.

\section{SIMPULAN DAN SARAN}

Berdasarkan hasil analisa, perancangan, implementasi dan pengujian yang dilakukan pada sistem pakar diagnosa penyakit paruparu berbasis java ini, maka dapat diambil kesimpulan bahwa sistem pakar diagnosa penyakit paru-paru yang dibuat dapat dioperasikan secara offline oleh petugas klinik sehingga dapat mempercepat proses pendiagnosaan penyakit pasien serta mempermudah dalam pembuatan laporan dan perhitungan statistik penderita penyakit berdasarkan periode waktu tertentu. Pasien tidak perlu menunggu lama untuk berkonsultasi dengan dokter, melainkan cukup mendaftarkan diri pada bagian administrasi kemudian menyebutkan gejalagejala yang dialaminya dan langsung mengetahui hasil diagnosa penyakit yang dideritanya sehingga proses pelayanan dapat lebih efektif dan efisien.

Adapun saran dari penulis mengenai aplikasi sistem pakar diagnosa penyakit paru-paru yang masih jauh dari sempurna. Penulis berharap aplikasi ini dapat dikembangkan lebih lagi seperti dibuat berbasis web atau android agar lebih fleksibel dan dapat digunakan secara online pada perangkat manapun sehingga pasien tidak perlu datang ke klinik. Serta data-data penyakit dan gejala harus selalu di-update agar dapat mendiagnosa penyakit-penyakit paru-paru terbaru dan data-datanya harus selalu dibackup untuk menghindari kehilangan data.

\section{DAFTAR PUSTAKA}

Amalia, I. M., Arifianto, D., \& Nilogiri, A. (2017). Sistem Pakar Diagnosa Penyakit Paru-paru Menggunakan Metode Certainty Factor Berbasis Web. Journal of Undergraduate Thesis, 1-13.

Hayadi, B. H. (2018). Sistem Pakar (1st ed., pp. 1-81). Deepublish.

Kusumaningtyas, D. D., Hasbi, M., \& Wijayanto, H. (2019). Sistem Pakar Diagnosa Penyakit Saluran Pernafasan dengan Metode Fuzzy Tsukamoto. TIKomSiN, 7(2), 1-7.

Nasution, Y. R., \& Khairuna. (2017). Sistem Pakar Deteksi Awal Penyakit Tuberkulosis dengan Metode Bayes. KLOROFIL, 1(1), 17-23.

Nazir, M. (2014). Metode Penelitian (10th ed., pp. 1-486). Ghalia Indonesia.

Pusat Layanan Kesehatan, A. (2021). Waspadai TBC Di Kala Pandemi. Pusat Layanan Kesehatan Universitas Airlangga.

http://plk.unair.ac.id/waspadai-tbc-dikala-pandemi/

Putra, F. (2011). Perancangan Sistem Pakar Identifikasi Penyakit Paru- Paru Menggunakan Metode Forward Chaining (pp. 1-138). Universitas Islam Negeri Syarif Hidayatullah Jakarta.

Putri, M. R. D. (2021). Kematian Akibat Kanker Paru Meningkat Pada 2020. ANTARA News. https://m.antaranews.com/amp/berita/20 17509/kematian-akibat-kanker-parumeningkat-pada-2020

Rahardjo, M. (2011). Memahami (Sekali Lagi) Grounded Research (pp. 1-7).

Sanubari, T., Prianto, C., \& Noviana, R. (2020). Odol (One Desa One Product Unggulan Online) Penerapan Metode Naive Bayes pada Pengembangan Aplikasi E-commerce Menggunakan Codeigniter (pp. 1-208). Kreatif. 